\section{Effects of Flame Weeding on Organic Garlic Production}

\author{
Lara Abou Chehade ${ }^{1}$, Marco Fontanelli, Luisa Martelloni, \\ Christian Frasconi, Michele Raffaelli, and Andrea Peruzzi
}

\begin{abstract}
ADDITIONAL INDEX wORDS. mechanical weeding, thermal weeding, integrated weed management, flaming, Allium sativum, organic farming
\end{abstract}

SUMMARY. A lack of efficient machines and strategies for cropping practices are still problems on small farms and in difficult landscapes, especially in organic crop production. The aim of this study was to develop a new weed control strategy for a typical organic garlic (Allium sativum) grown in Liguria, Italy. Flaming was proposed as an additional tool for the physical weed control program. A field experiment was conducted to test the effects of different flaming doses and timing on weed control and garlic production. The treatments consisted of a broadcast flaming at 16, 22, 37, and $112 \mathrm{~kg} \cdot \mathrm{ha}^{-1}$ of liquefied petroleum gas (LPG) at three different crop growth stages-emergence $(\mathrm{BBCH} 9)$, three to four leaves $(\mathrm{BBCH}$ 13 ) and six to seven leaves ( $\mathrm{BBCH} 16)$ - once (at each growth stage separately), twice (at $\mathrm{BBCH} 9$ and $\mathrm{BBCH} 13, \mathrm{BBCH} 9$ and $\mathrm{BBCH} \mathrm{16,} \mathrm{and} \mathrm{BBCH} 13$ and BBCH 16 stages) or three times (all stages combined). Treatments were compared with a weedy control and hand weeding. One flaming treatment was effective in controlling weeds during the growing season. Frequent flaming treatments did not further reduce the weed biomass measured at harvest. A higher production than the weedy control, in terms of the number of marketable bulbs and yield, was obtained for all the flaming interventions carried out at more than $16-\mathrm{kg} \cdot \mathrm{ha}^{-1} \mathrm{LPG}$ dose. Garlic flamed once at BBCH 13 at any LPG dose or three times at more than $16 \mathrm{~kg} \cdot \mathrm{ha}^{-1}$ led to a comparable number of bulbs as hand weeding. Three flamings at an LPG dose of $22 \mathrm{~kg} \cdot \mathrm{ha}^{-1}$ also gave a statistically similar yield to hand weeding. In general, garlic was shown to tolerate up to three flaming treatments without a decline in the production. The decline in yield compared with hand weeding could be offset by the economical savings of the mechanization process and by integrating flaming with other mechanical tools used for weed management.

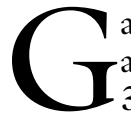
arlic is a minor crop in Italy and is produced on more than 3400 ha (Istituto Nazionale di Statistica, 2017). Many regions of Italy have production areas characterized by typical cultivars. Some of these areas are mountainous and the agricultural activities are carried out on small terraces, as in the case of Vessalico village in the province of Imperia. The long tradition of garlic production in this area makes it a highquality niche product and, in most cases, following organic production practices which improves the market value. However, traditional production

Department of Agriculture, Food and Environment, University of Pisa, Pisa 56124, Italy

We would like to thank Regione Liguria for funding this research within the project MARTE+ under the program of the European Regional Development Fund. We would like also to thank the farmers of the "A Resta" cooperative (Vessalico, Italy) and the staff of the Centro di Ricerche Agro-Ambientali "Enrico Avanzi" (CiRAA) of the University of Pisa for their technical support.

${ }^{1}$ Corresponding author. E-mail: lara.abouchehade@ agr.unipi.it.

https://doi.org/10.21273/HORTTECH04081-18 and cultivation practices are inefficient, laborious, time-consuming, and costly. The mechanization of the production chain (sowing, weed control and harvesting) would make garlic production more profitable by reducing the losses and costs above all of weed control, thus, releasing time and labor to be used elsewhere in production (Melander et al., 2005).

Weeds limit crop yield and quality, and weed control is one of the most challenging crop management practices (Liebman and Davis, 2009). In organic farming, synthetic herbicides are not permitted and weed control is often limited to physical means where hand weeding and cultivation are the most popular (Datta and Knezevic, 2013). Garlic is a slowgrowing bulb crop that is small in size, has shallow roots, and a thin canopy, which make it a poor competitor with weeds (Duranti and Cuocolo, 1989). Hand weeding requires labor availability and is expensive. Repeated cultivations increase soil disturbance and contribute to the destruction of the soil structure, loss of organic matter, and increase the chances of soil erosion (Wszelaki et al., 2007).

Flame weeding has been proposed as an alternative to these traditional techniques both in organic and conventional agricultural systems. In the latter, herbicide-resistant weeds and the pollution of surface and groundwater by herbicide residues have also raised public concerns and restrictions on herbicide use, which demand other alternatives (Datta and Knezevic, 2013; Rifai et al., 2002; Wszelaki et al., 2007).

Flame weeding exposes weeds to heat stress, which causes the denaturation of membrane proteins resulting in a loss of cell function and dehydration and leading to their death or a reduction in their competitive ability (Carrubba and Militello, 2013; Datta and Knezevic, 2013; Laguë et al., 2001). Plant response to flaming depends on their heat tolerance (Ascard, 1995). The susceptibility to heat stress is primarily speciesspecific, depending also on the position of the growing point and the growth stage of the plant (Cisneros and Zandstra, 2008; Ulloa et al., 2010).

\begin{tabular}{lllc}
\hline $\begin{array}{l}\text { Units } \\
\begin{array}{l}\text { To convert U.S. to SI, } \\
\text { multiply by }\end{array}\end{array}$ & U.S. unit & SI unit & $\begin{array}{l}\text { To convert SI to U.S., } \\
\text { multiply by }\end{array}$ \\
\hline 0.4047 & $\mathrm{acre}(\mathrm{s})$ & $\mathrm{ha}$ & 2.4711 \\
0.3048 & $\mathrm{ft}$ & $\mathrm{m}$ & 3.2808 \\
0.0929 & $\mathrm{ft}^{2}$ & $\mathrm{~m}^{2}$ & 10.7639 \\
2.54 & inch(es) & $\mathrm{cm}$ & 0.3937 \\
25.4 & inch $(\mathrm{es})$ & $\mathrm{mm}$ & 0.0394 \\
0.4536 & $\mathrm{lb}$ & $\mathrm{kg}$ & 2.2046 \\
0.1121 & $\mathrm{lb} / \mathrm{acre}$ & $\mathrm{g} \cdot \mathrm{m}^{-2}$ & 8.9218 \\
1.1209 & $\mathrm{lb} / \mathrm{acre}$ & $\mathrm{kg} \cdot \mathrm{ha}^{-1}$ & 0.8922 \\
1.6093 & $\mathrm{mph}$ & $\mathrm{km} \cdot \mathrm{h}^{-1}$ & 0.6214 \\
0.0069 & $\mathrm{psi}$ & $\mathrm{MPa}$ & 145.0377 \\
2.2417 & ton $(\mathrm{s}) / \mathrm{acre}$ & $\mathrm{t} \cdot \mathrm{ha}^{-1}$ & 0.4461 \\
$\left({ }^{\circ} \mathrm{F}-32\right) \div 1.8$ & ${ }^{\circ} \mathrm{F}$ & ${ }^{\circ} \mathrm{C}$ & $\left({ }^{\circ} \mathrm{C} \times 1.8\right)+32$
\end{tabular}


Flaming does not disrupt the soil surface and does not contribute to germination of new flushes of weed seeds brought to the surface (Wszelaki et al., 2007). This weed control strategy can be used when fields are too wet or stony for cultivation. It has been used primarily before the crop emergence, especially in slow-growing vegetables (Ascard, 1995; Datta and Knezevic, 2013). Postemergence treatments have been found to be promising in heat-tolerant crops, such as maize (Zea mays), soybean (Glycine max), sorghum (Sorghum bicolor), and onion (Allium cepa) (Knezevic et al., 2013; Martelloni et al., 2016a; Sivesind et al., 2012; Ulloa et al., 201 la, 201lb).

However, using flaming as the only weed control tool can be costly and somewhat ineffective when weeds and the crop are not at the optimal growth stage for interventions. Integrated physical weed control based on the use of mechanical and thermal methods can lower intrarow weed control requirements and give satisfactory results, provided that they are used in combination (Melander et al., 2005; Stepanovic et al., 2016; Taylor et al., 2012). Our preliminary research on flame weeding in garlic cultivation showed positive results when postemergence broadcast flaming was performed, ensuring a lower weed biomass and higher garlic yields compared with weedy controls (Fontanelli et al., 2015a).

For an optimal weed control, the response of garlic production systems to flaming must be studied thoroughly and the optimal dose of liquefied petroleum gas, the growth stage and number of weeding interventions need to be defined. Our study was carried out during 2011-12 to develop a physical weed control strategy for garlic cultivation in complex landscapes. The aim was to test the effects of flaming intensities (i.e., different LPG doses obtained using a single LPG pressure of $0.2 \mathrm{MPa}$ applied at different tractor driving speeds) and time of intervention (defined by the growth stage of the garlic plant) on the weeds and yield attributes of garlic. The study addressed the specific geographical and growing conditions of 'Vessalico' garlic, a typical product of the province of Imperia in Liguria, northwest Italy, managed under organic farming practices.

\section{Materials and methods}

EQUIPMENT AND EXPERIMENTAL SET UP. The field experiment was conducted in the 2011-12 season at an organic certified farm located in Vessalico (lat. $44^{\circ} 2^{\prime} 48^{\prime \prime} \mathrm{N}$, long. $7^{\circ} 57^{\prime} 35^{\prime \prime} \mathrm{E}$ ) in northern Italy. The area is characterized by a Mediterranean climate and a sand loamy soil (Table 1). Garlic gloves were planted with a customized 1.5 -m-wide mechanical precision planter (JJ Broch, Madrid, Spain) in mid-Jan. 2012, with $10 \mathrm{~cm}$ within rows and $20 \mathrm{~cm}$ between rows, for a total of five rows. Before garlic planting, a false seed bed (Fontanelli et al., 2013; Raffaelli et al., 2010, 2011) was created by two passes with a rolling harrow (Fig. 1). Starting at crop emergence, plots were subjected to different flaming treatments at four different LPG doses $\left(16,22,37\right.$, and $\left.112 \mathrm{~kg} \cdot \mathrm{ha}^{-1}\right)$, obtained using four tractor speeds $\left(1,3,5\right.$, and $\left.7 \mathrm{~km} \cdot \mathrm{h}^{-1}\right)$ at a constant working pressure of $0.2 \mathrm{MPa}$. These four flaming treatments were applied at three different crop growth stages-emergence (BBCH 9), three to four leaves (BBCH 13), and six to seven leaves (BBCH 16). The flaming treatments were applied either once (at each growth stage separately), twice (at $\mathrm{BBCH} 9$ and $\mathrm{BBCH} 13, \mathrm{BBCH} 9$ and $\mathrm{BBCH} 16$, and $\mathrm{BBCH} 13$ and $\mathrm{BBCH} 16$ stages), or thrice (all stages combined). Garlic growth stages followed the identification of Feller et al. (1995).

A total of 28 treatments were carried out over plots of $1 \times 7 \mathrm{~m}$, replicated three times in a randomized block design using a controlled traffic system. Treatments were compared with a weedy control and a hand weeding treatment both also replicated three times, imitating traditional weed control. The flaming machine was developed by the University of Pisa and is characterized by six $25-\mathrm{cm}$-wide prismatic $\mathrm{rod}$ burners, with a total width of $1.5 \mathrm{~m}$ (Fig. 2). The machine is equipped with four 25-kg LPG tanks (Raffaelli et al., 2013, 2015). The burners of the flaming machine were set at a constant working pressure of $0.2 \mathrm{MPa}$.

During the growing season, two mechanical weed controls were carried out by the precision hoe for interand intrarow weed control (Fig. 3).
Precision hoeing was used to avoid damage to the crop. The distance between garlic rows was reduced in our experiment to $20 \mathrm{~cm}$, to exploit

Table 1. Physical and chemical characteristics of the soil in the experimental field used to test the effects of flaming on organic garlic production.

\begin{tabular}{lc}
\hline Parameter & Value \\
\hline $\mathrm{pH}$ & 8 \\
Clay & $12.04 \%$ \\
Silt & $40.6 \%$ \\
Sand & $47.36 \%$ \\
Organic matter & $4.76 \%$ \\
Gravel & $8.4 \%$ \\
\hline
\end{tabular}

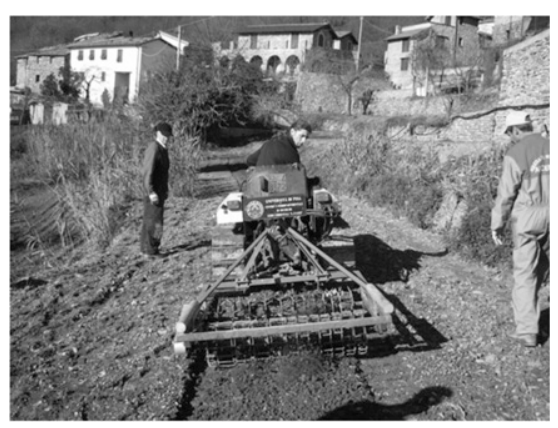

Fig. 1. The rolling harrow used to create the false seed bed for weed control before garlic planting.

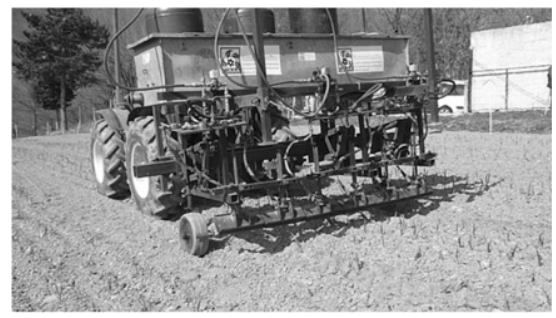

Fig. 2. The flaming machine equipped with six burners used for broadcast flaming.

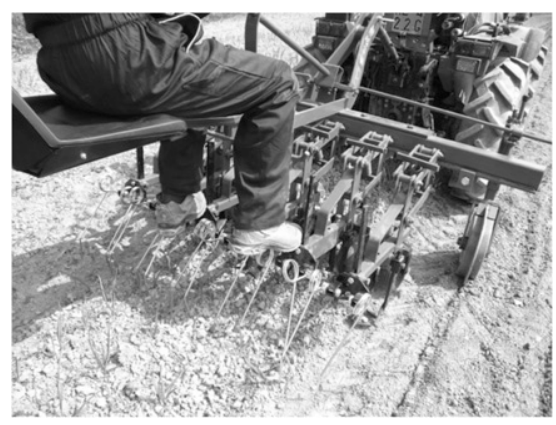

Fig. 3. The precision hoe used for inter- and intrarow weed control during garlic-growing season. 
better the farm. The machine was customized by MIPE Viviani (Monteriggioni, Italy) and can easily be adapted to narrow row crops. It is equipped with six rigid blades for interrow weed control and couples of elastic tines for in-row selective weed control. The trajectory of the precision hoe can be adjusted with a manual guidance system in real time by a back-seated operator driving the machine (Fontanelli et al., 2015b; Peruzzi et al., 2007, 2017).

Data collection. Garlic bulbs were sampled in mid-July 2012 over an area of $0.5 \times 0.3 \mathrm{~m}^{2}$, on which yields were measured considering all bulbs harvested. Bulbs were then graded according to their size, and only those with a $50-60 \mathrm{~mm}$ diameter were recorded, as they are the preferred grade for consumers. Weed dry biomass at harvest was also measured over the same area after drying at $100{ }^{\circ} \mathrm{C}$ till a constant weight was obtained. Weed flora composition during garlic-growing season is shown in Table 2.

Statistical analysis. The effects of LPG doses, timing, and their interactions on weed dry biomass and garlic bulb dry yields were tested with the analysis of variance of linear mixed effects models using the lmerTest package (Kuznetsova et al., 2018) of $\mathrm{R}$ statistical software (R Core Team, 2017). The numbers of garlic bulbs were modeled according to a Poisson distribution with generalized linear models. Nonsignificant fixed effects and interactions were excluded from models. Least square means of the variables as affected by the different treatments were estimated with the lsmeans package (Lenth and Love, 2018). Differences between the number of flaming interventions were obtained using the drc package (Ritz and Streibig, 2005). Least square means were considered different when the 95\% confidence interval (CI) of the pairwise difference did not cross the value 0 . The CI for the difference between two group means was computed using the following equation (Knezevic, 2008):

$$
\begin{aligned}
& \mathrm{CI} \text { (difference) } \\
& \quad=x_{1}-x_{2} \pm 1.96 \sqrt{\left(\mathrm{SE}_{x 1}\right)^{2}+\left(\mathrm{SE}_{x 2}\right)^{2}},
\end{aligned}
$$

where $x_{1}$ is the value of the first least squares mean, $x_{2}$ is the value of the second least squares mean, SE is the standard error of $x_{1}$ and $x_{2}$, respectively, and 1.96 is the critical $t$-value.

\section{Results}

ONE FLAMING TREATMENT. Weed flora in the field, as shown in Table 2, consisted exclusively of dicotyledonous weeds, mainly the perennial field bindweed [Convolvulus arvensis (31\%)] and the annual cleavers [Galium aparine $(26 \%)$ ], whereas remaining weeds were all annuals. Weeds classified as others in Table 2 were mainly common chickweed (Stellaria media), perennial sowthistle (Sonchus arvensis), and groundsel (Senecio pulgaris). Weed biomass at harvest was affected by the timing of flaming when performed once during the garlic-growing season $(P<0.001)$. One flaming at crop $\mathrm{BBCH} 9$ reduced weed infestation $\left(64.6 \mathrm{~g} \cdot \mathrm{m}^{-2}\right)$ by more than $40 \%$ compared with flaming at advanced stages (110.4 and $160.5 \mathrm{~g} \cdot \mathrm{m}^{-2}$ for $\mathrm{BBCH} 13$ and $\mathrm{BBCH}$ 16, respectively) and by around $64 \%$ compared with hand weeding $\left(180 \mathrm{~g} \cdot \mathrm{m}^{-2}\right)($ Fig. $4 \mathrm{~A})$. All the different flaming treatments were effective in controlling weeds, whereas early flaming treatments performed at stages $\mathrm{BBCH} 9$ or at $\mathrm{BBCH} 13$ were also more effective than hand weeding (Fig. 4A). The response of garlic to flaming in terms of the

Table 2. Dominant weed species observed in the field during garlic-growing season.

\begin{tabular}{llc}
\hline Common name & Scientific name & Weed presence (\%) \\
\hline Field bindweed & Convolvulus arvensis & 31 \\
Cleavers & Galium aparine & 26 \\
Persian speedwell & Veronica persica & 9 \\
Lamb's-quarters & Chenopodium album & 7 \\
Others & - & 27 \\
\hline
\end{tabular}
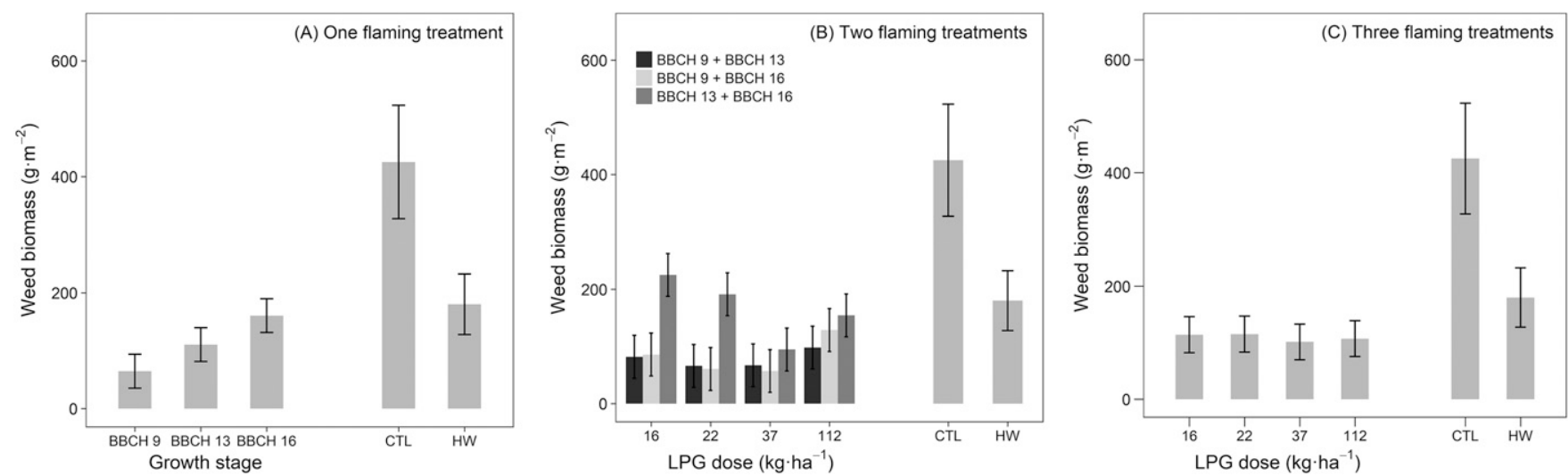

Fig. 4. Weed biomasses at harvest and their $95 \%$ confidence intervals as affected by garlic growth stage and/or liquefied petroleum gas (LPG) dose with (A) one, $(\mathrm{B})$ two, and (C) three flaming treatments; $\mathrm{BBCH} 9=$ emergence, $\mathrm{BBCH} 13=$ three to four leaves, $\mathrm{BBCH} 16=$ six to seven leaves, $\mathrm{CTL}=$ weedy control, $\mathrm{HW}=$ hand weeding; $1 \mathrm{~kg} \cdot \mathrm{ha}^{-1}=0.8922 \mathrm{lb} / \mathrm{acre}, 1 \mathrm{~g} \cdot \mathrm{m}^{-2}=$ $8.9218 \mathrm{lb} /$ acre. 
number of marketable bulbs produced was affected by the interaction between the plant growth stage and the LPG dose $(P=0.009)$. When increasing the LPG dose to $37 \mathrm{~kg} \cdot \mathrm{ha}^{-1}$ and more, the number of garlic bulbs increased in garlic flamed at $\mathrm{BBCH}$ 16. Flaming at other stages was unaffected by the change in LPG dose. However, garlic flamed at $\mathrm{BBCH} 13$ generally showed a better response to flaming and had a higher number of marketable bulbs than garlic flamed at $\mathrm{BBCH} 9$ and $\mathrm{BBCH} 16$, at any LPG dose (Fig. 5A). At this stage (i.e., $\mathrm{BBCH} 13$ ), marketable bulb production was similar to hand weeding. Garlic production was generally similar for $\mathrm{BBCH} 9$ and $\mathrm{BBCH} 16$, with yields exceeding the weedy control but still inferior to yields achieved with hand weeding.

The low production of marketable bulbs when flaming was carried out at $\mathrm{BBCH} 16$ stage could be attributed to higher weed stress causing the bulbs to not grow well and reach the dimensions required, whereas the heat stress may have affected bulbs during their early growth (BBCH 9). LPG dose had no effect on marketable bulbs when garlic was flamed at $\mathrm{BBCH}$ 9. At $\mathrm{BBCH} 13$, the only decrease in bulbs was observed when the dose decreased from 22 to $16 \mathrm{~kg} \cdot \mathrm{ha}^{-1}$. Plants flamed at $\mathrm{BBCH} 16$ were more affected by the flaming dose and the decline was gradual when decreasing the dose from 112 to $16 \mathrm{~kg} \cdot \mathrm{ha}^{-1}$ (Fig. $5 \mathrm{~A})$. Plant stress was also observed with suppressed yield relative to hand weeding (Fig. 6A), probably due to lower dry matter content and/or favoring smaller bulbs in the same marketable range $(50-60 \mathrm{~mm})$. Regardless of the LPG dose, lower yields were obtained from plants flamed at $\mathrm{BBCH} 9$ and $\mathrm{BBCH} 16$ compared with those flamed at $\mathrm{BBCH} 13(P=$ $0.002)$.
Two flaming treatments. When two flaming treatments were performed, weed biomass at harvest was the result of the interaction between the garlic growth stage at the time of the intervention and the LPG dose $(P=0.01)$. All four flaming doses maintained similarly low weed biomass applied twice at $\mathrm{BBCH} 9+$ $\mathrm{BBCH} 13$ or $\mathrm{BBCH} 9+\mathrm{BBCH} 13$ (Fig. 4B). For the two flaming treatments at $\mathrm{BBCH} 13$ and $\mathrm{BBCH} 16$, weed biomass was the highest for the 16- and $22-\mathrm{kg} \cdot \mathrm{ha}^{-1}$ doses but significantly declined with the $37-\mathrm{kg} \cdot \mathrm{ha}^{-1}$ dose (Fig. 4B). Both stages (i.e., $\mathrm{BBCH} 9+\mathrm{BBCH} 13$ and $\mathrm{BBCH}$ $9+\mathrm{BBCH}$ 16), when the dose was decreased to 22 and $16 \mathrm{~kg} \cdot \mathrm{ha}^{-1}$ showed less residual weed biomass than $\mathrm{BBCH} 13+\mathrm{BBCH} 16$ stage. All flaming treatments controlled weeds effectively compared with the weedy control and in almost all cases were better than hand weeding (Fig. 4B).
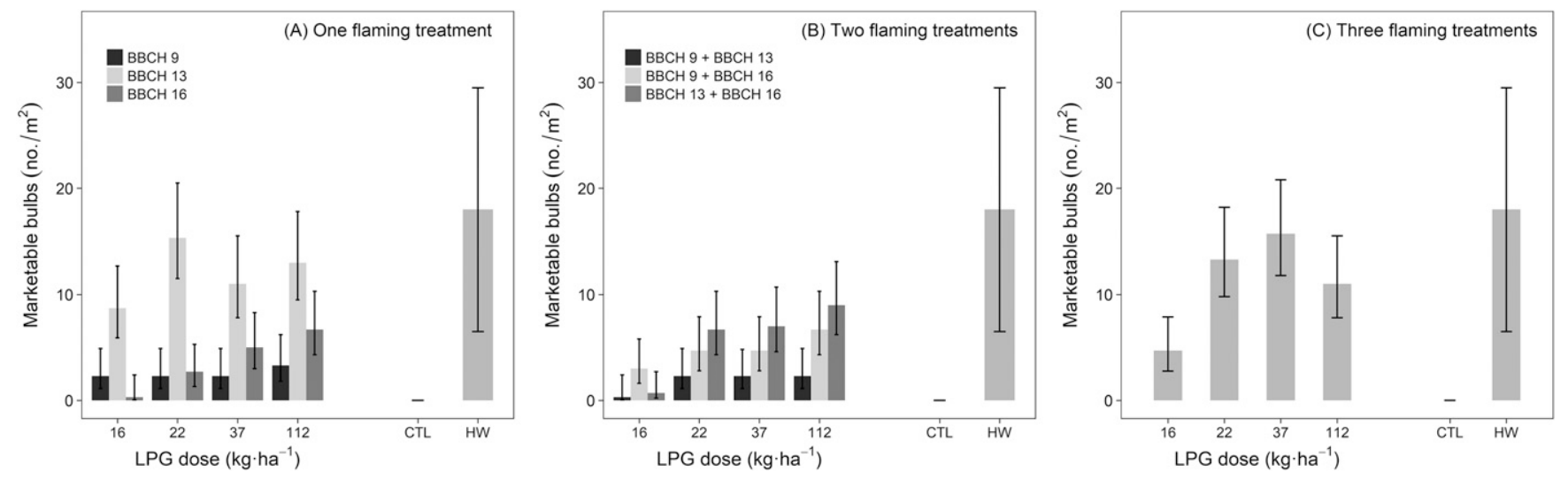

Fig. 5. Numbers of marketable garlic bulbs and their $\mathbf{9 5 \%}$ confidence intervals as affected by growth stage and/or liquefied petroleum gas (LPG) dose with (A) one, $(\mathrm{B})$ two, and $(\mathrm{C})$ three flaming treatments; $\mathrm{BBCH} 9=$ emergence, $\mathrm{BBCH} 13=$ three to four leaves, $\mathrm{BBCH} 16$ = six to seven leaves, $\mathrm{CTL}=$ weedy control, $\mathrm{HW}=$ hand weeding; $1 \mathrm{bulb} / \mathrm{m}^{2}=0.0929 \mathrm{bulb} / \mathrm{ft}^{2}$.
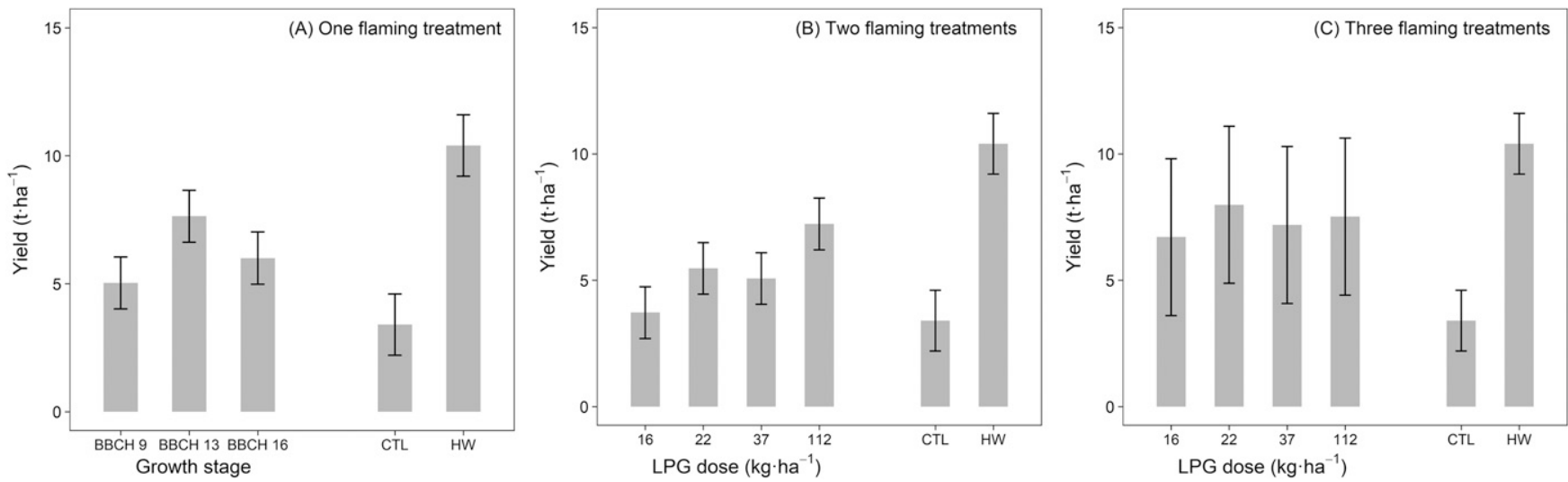

Fig. 6. Garlic yields and their $95 \%$ confidence intervals as affected by growth stage or liquefied petroleum gas (LPG) dose with (A) one, (B) two, and (C) three flaming treatments; $\mathrm{BBCH} 9=$ emergence, $\mathrm{BBCH} 13=$ three to four leaves, $\mathrm{BBCH} 16=$ six to seven leaves, $\mathrm{CTL}=$ weedy control, $\mathrm{HW}=$ hand weeding; $1 \mathrm{~kg} \cdot \mathrm{ha}^{-1}=0.8922 \mathrm{lb} / \mathrm{acre}, 1 \mathrm{t} \cdot \mathrm{ha}^{-1}=0.4461 \mathrm{ton} / \mathrm{acre}$. 
Compared with one flaming at $\mathrm{BBCH} 9$ (Fig. 4A), two flaming treatments did not control more weeds.

The production of bulbs after two flamings was affected by both the flaming dose $(P<0.001)$ and time of intervention $(P<0.001)$ as shown in Fig. 5B. A flaming at $\mathrm{BBCH} 9+$ $\mathrm{BBCH} 13$ resulted in the lowest production of marketable bulbs compared with flaming performed at $\mathrm{BBCH} 9+\mathrm{BBCH} 16$ or at $\mathrm{BBCH}$ $13+\mathrm{BBCH} 16$ stage. In addition, the lower the LPG dose, the lower the yield production. Marketable bulbs were the lowest with the $16-\mathrm{kg} \cdot \mathrm{ha}^{-1}$ dose, and showed noticeable increases at higher LPG dose (Fig. 5B). Garlic yield, which followed trends similar to marketable bulbs, decreased from 7.2 to $3.7 \mathrm{t} \cdot \mathrm{ha}^{-1}$ when the flaming dose decreased from 112 to $16 \mathrm{~kg} \cdot \mathrm{ha}^{-1}[P<0.001$ (Fig. 6B)] but remained higher than the nonflamed weedy control except for an LPG dose of $16 \mathrm{~kg} \cdot \mathrm{ha}^{-1}$. Garlic yields after two flamings were less than the yield after hand weeding at any dose adopted. Performing two flaming events (Fig. 6B) did not ensure higher yields than one flaming event (Fig. 6A).

The trends obtained previously highlighted the interaction between both the crop and weeds present in the field at the same time of flaming. Weed sensitivity to flaming, weed crop competition, and the degree of crop stress to heat are factors that can affect final garlic bulb marketability and yield.

Three flaming treatments. For three flaming events during the growing season, the different LPG doses had no effect on weed biomass $[P=0.792$ (Fig. 4C)]. No further weed control was provided in this case compared with one or two passes of flaming. Garlic yield, although at this point unaffected by the flaming dose $(P=0.921)$, showed interestingly a statistically comparable yield with the hand-weeded control at 22 $\mathrm{kg} \cdot \mathrm{ha}^{-1}[95 \% \mathrm{CI}$ ranging between -5.30 and 0.46 (Fig. 6C)]. At such a dose $\left(22 \mathrm{~kg} \cdot \mathrm{ha}^{-1}\right)$ and greater, the number of marketable bulbs was also similar to that of hand weeding $[P<$ 0.001 (Fig. 5C)].

\section{Discussion}

Crop response to flame weeding varies with species and growth stage
(Datta and Knezevic, 2013; Ulloa et al., 2010, 2011). In our case, garlic plants flamed at three- to four-true leaf stages $(\mathrm{BBCH} \mathrm{13)}$ were the most tolerant, whereas those flamed at both emergence $(\mathrm{BBCH} 9)$ or the six- to seven-leaf stages (BBCH 16) were similar in their susceptibility to heat stress (Fig. 5A). Differences in crop susceptibility to heat have been found with soybean, where a lower injury was obtained when plants were flamed at emergence or fifth trifoliate, once at each stage or combined (Knezevic et al., 2013).

Plant size at the time of flaming has a great influence on plant sensitivity, with small plants generally being more sensitive than large ones. At advanced stages, plants are more likely to have developed adventitious axillary buds protected by thick petioles and lignified stems (Ascard, 1994; Bond and Grundy, 2001). The larger surface area and greater biomass of older plants, which require a higher fuel dose to be heated, also affect their susceptibility to flaming (Ascard, 1995, 1998). In monocotyledonous plants, the growing point is well protected because it is typically at the base of the plant in the center of the leaf sheaths, which is often below soil level even for plants at the cotyledon stage (Merfield et al., 2017).

However, plant tolerance has sometimes been shown to be selective at later stages of growth, as in our case (Fig. 5A). Ulloa et al. (2011) showed a higher tolerance in maize when broadcast flaming was performed at the five-leaf stage than at seven-leaf and two-leaf stages, where the highest crop injury, dry matter reductions, and yield loss occurred. A higher number of marketable garlic bulbs obtained in our study when operating at a high flaming dose (Fig. 5A and B) also was found by Wszelaki et al. (2007).

Garlic has a high resistance to thermal weeding and can tolerate three postemergence flame weedings without a noticeable decrease in production.

Although in our case, one flaming at three to four leaves ensured a similar number of marketable bulbs compared with hand weeding (Fig. $5 \mathrm{~A}$ ), it was not enough to avoid yield loss (Fig. 6A). Our results are in agreement with Sivesind et al. (2012) when onions were flamed.
Tractor speed, which affects the LPG dose, plays a role in weed survival although in our case the end season weed biomass did not always show this (Fig. 4A and C). In a previous study conducted by our research group on garlic, weed biomass at harvest was reduced by increasing the working pressure of the flaming machine from 0.2 to $0.3 \mathrm{MPa}$, thus, increasing the LPG dose per hectare (Fontanelli et al., 2015a).

However, the growing stage of weed species also affects how they respond differently to heat sources and operational speed/LPG working pressures and doses (Knezevic et al., 2014; Merfield et al., 2017). For successful weed control, flaming could be repeated frequently taking into consideration an early growth stage and the small size of weeds (Ascard, 1994; Martelloni et al., $2016 b, 2017)$. Weeds at the cotyledon to two-leaf stage are the most susceptible up to $72 \mathrm{~kg} \cdot \mathrm{ha}^{-1}$ of LPG according to Sivesind et al. (2009). This could explain our results of a decreased weed biomass at harvest, when one flaming was performed at early crop growth stages or a double flaming including emergence stage. Weeds at later stages of growth are more tolerant to flaming and an early intervention is effective in controlling them.

This study highlights the need for an integrated weed control during the growing season. A mechanical weed intervention (e.g., precision hoeing or finger weeding) should be adopted for sown crops characterized by a reduced interrow distance, lower competitiveness, longer critical period, and small seedlings in the first part of the growth cycle. These treatments should be repeated throughout the critical period, depending on the weed infestation levels, interrow width, and crop growth stage (Pannacci et al., 2017).

Although manual weeding is often required in organic cropping systems, combining flaming with mechanical cultivation may optimize weed control on organic vegetable farms. Successful examples have been reported in Fontanelli et al. (2015b) and Peruzzi et al. (2007) when combining both flaming and precision hoeing in a physical weed control for spinach (Spinacia oleracea) and carrot (Daucus carota) production. 


\section{Conclusions}

Weed control was achieved with one pass of flaming during the growing season of garlic. Garlic showed a reasonable tolerance to flaming and was able to withstand up to three flamings. A single flaming at three to four leaves at any flaming dose appears to be a viable option for maintaining high marketable bulbs compared with two and three flaming options. However, three flamings ensured a timely weed control at plant key growth stages and was shown to be promising in preventing yield loss. The experiment also highlighted the need for an integrated weed control strategy. Beside other mechanical means, flaming potentially could be used by organic garlic growers to replace laborious hand weeding. Being dependent on the response of the plant, weather conditions, and weed infestation in the field, the intervention at the most appropriate growth stage and the flaming technique (LPG pressure, tractor driving speed, and the number of treatments) are important for the success of the strategy adopted.

\section{Literature cited}

Ascard, J. 1994. Dose-response models for flame weeding in relation to plant size and density. Weed Res. 34:377-385.

Ascard, J. 1995. Effects of flame weeding on weed species at different developmental stages. Weed Res. 35:397-411.

Ascard, J. 1998. Comparison of flaming and infrared radiation techniques for thermal weed control. Weed Res. 38:6976.

Bond, W. and A.C. Grundy. 2001. Nonchemical weed management in organic farming systems. Weed Res. 41:383405 .

Carrubba, A. and M. Militello. 2013. Nonchemical weeding of medicinal and aromatic plants. Agron. Sustain. Dev. 33:551-561.

Cisneros, J.J. and B.H. Zandstra. 2008. Flame weeding effects on several weed species. Weed Technol. 22:290-295.

Datta, A. and S.Z. Knezevic. 2013. Flaming as an alternative weed control method for conventional and organic agronomic crop production systems: A review. Adv. Agron. 118:399-428.

Duranti, A. and L. Cuocolo. 1989. Chemical weed control and mulching in onion (Allium cepa L.) and garlic (Allium sativum L.). Adv. Hort. Sci. 3:7-12.

Feller, C., L. Bleiholder, L. Buhr, H. Hack, M. Hess, R. Klose, U. Meier, R. Strauss, T. van der Boom, and E. Weber. 1995. Phänologische entwicklungsstadien von gemüsepflanzen: I. Zwiebel-, wurzel-, knollen- und blattgemüse. Nachrichtenblatt des Deutschen Pflanzenschutzdienstes 47:217-232.

Fontanelli, M., C. Frasconi, L. Martelloni, M. Pirchio, M. Raffaelli, and A. Peruzzi. 2015a. Innovative strategies and machines for physical weed control in organic and integrated vegetable crops. Chem. Eng. Trans. 44:211-216.

Fontanelli, M., L. Martelloni, M. Raffaelli, C. Frasconi, M. Ginanni, and A. Peruzzi. $2015 \mathrm{~b}$. Weed management in autumn fresh market spinach: A nonchemical alternative. HortTechnology 25:177-184.

Fontanelli, M., M. Raffaelli, L. Martelloni, C. Frasconi, M. Ginanni, and A. Peruzzi. 2013. The influence of non-living mulch, mechanical and thermal treatments on weed population and yield of rainfed freshmarket tomato (Solanum lycopersicum L.). Span. J. Agr. Res. 11:593-602.

Istituto Nazionale di Statistica. 2017. Istat.it: Agricoltura e zootecnia. 27 Apr. 2018. $<$ http://agri.istat.it/jsp/dawinci.jsp?

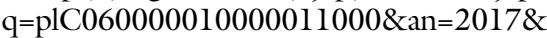
ig $=1 \& c t=248 \& \mathrm{id}=15 \mathrm{~A}|18 \mathrm{~A}| 28 \mathrm{~A}>$.

Knezevic, A. 2008. Overlapping confidence intervals and statistical significance. 27 Apr. 2018. <https://www.cscu. cornell.edu/news/statnews/stnews73. pdf $>$.

Knezevic, S.Z., S. Stepanovic, and A. Datta. 2014. Growth stage affects response of selected weed species to flaming. Weed Technol. 28:233-242.

Knezevic, S.Z., S. Stepanovic, A. Datta, D. Nedeljkovic, and N. Tursun. 2013. Soybean yield and yield components as influenced by the single and repeated flaming. Crop Protection 50:1-5.

Kuznetsova, A., P.B. Brockhoff, and R.H. B. Christensen. 2018. lmerTest: Tests in linear mixed effects models. 27 Apr. 2018. <https://cran.rproject.org/web/packages/ lmerTest/index.html>

Laguë, C., J. Gill, and G. Péloquin. 2001. Thermal control in plant protection, $\mathrm{p}$. 35-46. In: C. Vincent, B. Panneton, and F. Fleurat-Lessard (eds.). Physical control methods in plant protection. Springer, Berlin/Heidelberg, Germany.

Lenth, R. and J. Love. 2018. 1smeans: Least-squares means. 27 Apr. 2018. <https://cran.r-project.org/web/ packages/lsmeans/index.html>.
Liebman, M. and A.S. Davis. 2009. Managing weeds in organic farming systems: An ecological approach, p. 173-196. In: C. Francis (ed.). Organic farming: The ecological system. Amer. Soc. Agron., Madison, WI.

Martelloni, L., M. Fontanelli, C. Frasconi, M. Raffaelli, and A. Peruzzi. 2016a. Cross-flaming application for intra-row weed control in maize. Appl. Eng. Agr. 32:569-578.

Martelloni, L., M. Fontanelli, C. Frasconi, M. Raffaelli, M. Pirchio, and A. Peruzzi. 2017. A combined flamer-cultivator for weed control during the harvesting season of asparagus green spears. Span. J. Agr. Res. 15:e0203.

Martelloni, L., C. Frasconi, M. Fontanelli, M. Raffaelli, and A. Peruzzi. 2016b. Mechanical weed control on small-size dry bean and its response to cross-flaming. Span. J. Agr. Res. 14:e0203.

Melander, B., I.A. Rasmussen, and P. Bàrberi. 2005. Integrating physical and cultural methods of weed controlExamples from European research. Weed Sci. 53:369-381.

Merfield, C.N., J.G. Hampton, and S.D. Wratten. 2017. Efficacy of heat for weed control varies with heat source, tractor speed, weed species and size. N. Z. J. Agr. Res. 60:437-448.

Pannacci, E., B. Lattanzi, and F. Tei. 2017. Non-chemical weed management strategies in minor crops: A review. Crop Protection 96:44-58.

Peruzzi, A., M. Ginanni, M. Fontanelli, M. Raffaelli, and P. Bàrberi. 2007. Innovative strategies for on-farm weed management in organic carrot. Renew. Agr. Food Syst. 22:246-259.

Peruzzi, A., L. Martelloni, C. Frasconi, M. Fontanelli, M. Pirchio, and M. Raffaelli. 2017. Machines for nonchemical intra-row weed control in narrow and wide-row crops: A review. J. Agr. Eng. 48:57-70.

R Core Team. 2017. R: A language and environment for statistical computing. 13 June 2018. <https://www.R-project. org $/>$.

Raffaelli, M., M. Fontanelli, C. Frasconi, M. Ginanni, and A. Peruzzi. 2010. Physical weed control in protected leaf-beet in central Italy. Renew. Agr. Food Syst. $25: 8-15$.

Raffaelli, M., M. Fontanelli, C. Frasconi, F. Sorelli, M. Ginanni, and A. Peruzzi. 2011. Physical weed control in processing tomatoes in central Italy. Renew. Agr. Food Syst. 26:95-103. 
Preliminary and Regional Reports

Raffaelli, M., C. Frasconi, M. Fontanelli, L. Martelloni, and A. Peruzzi. 2015. LPG burners for weed control. Appl. Eng. Agr. 31:717-731.

Raffaelli, M., L. Martelloni, C. Frasconi, M. Fontanelli, and A. Peruzzi. 2013. Development of machines for flaming weed control on hard surfaces. Appl. Eng. Agr. 29:663-673.

Rifai, M.N., T. Astatkie, M. Lacko-Bartosova, and J. Gadus. 2002. Effect of two different thermal units and three types of mulch on weeds in apple orchards. J. Environ. Eng. Sci. 1:331-338.

Ritz, C. and J.C. Streibig. 2005. Bioassay analysis using R. J. Stat. Software 12:1-22.

Sivesind, E.C., M.L. Leblanc, D.C. Cloutier, P. Seguin, and K.A. Stewart. 2009. Weed response to flame weeding at different developmental stages. Weed Technol. 23:438-443.

Sivesind, E.C., M.L. Leblanc, D.C. Cloutier, P. Seguin, and K.A. Stewart. 2012. Impact of selective flame weeding on onion yield, pungency, flavonoid concentration, and weeds. Crop Protection 39:45-51.

Stepanovic, S., A. Datta, B. Neilson, C. Bruening, C.A. Shapiro, G. Gogos, and S. Z. Knezevic. 2016. Effectiveness of flame weeding and cultivation for weed control in organic maize. Biol. Agr. Hort. 32:4762.

Taylor, E.C., K.A. Renner, and C.L. Sprague. 2012. Organic weed management in field crops with a propane flamer and rotary hoe. Weed Technol. 26:793799.

Ulloa, S.M., A. Datta, C. Bruening, B. Neilson, J. Miller, G. Gogos, and S.Z.
Knezevic. 2011. Maize response to broadcast flaming at different growth stages: Effects on growth, yield and yield components. Eur. J. Agron. 34:10-19.

Ulloa, S.M., A. Datta, and S.Z. Knezevic. 2010. Tolerance of selected weed species to broadcast flaming at different growth stages. Crop Protection 29:1381-1388.

Ulloa, S.M., A. Datta, and S.Z. Knezevic. 2011. Growth stage influenced sorghum response to broadcast flaming: Effects on yield and its components. Agron. J. 103:7-12.

Wszelaki, A.L., D.J. Doohan, and A. Alexandrou. 2007. Weed control and crop quality in cabbage (Brassica oleracea (capitata group)) and tomato (Lycopersicon lycopersicum) using a propane flamer. Crop Protection 26:134-144. 